\title{
クラフトパルプエ程用新規薬剤*
}

\author{
サンノプコ株式会社 研究総括部 吉 内 圭 吾
}

\section{New Agents for Kraft Process}

Keigo Yoshiuchi

Research \& Development Dept. SAN NOPCO LIMITED

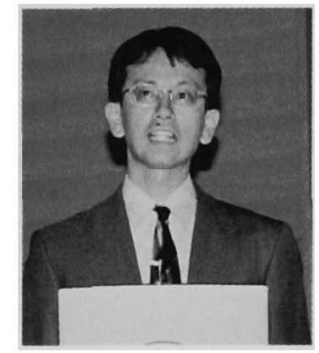

The Kraft process consists of the cooking process and the bleaching process mainly. In Kraft process, the weakest point is the low of the yield of pulp in the cooking process. The kinds of quinone derivatives or polysulfide derivatives are widely used as cooking assistant agents to improve it. "Cooking Ac-

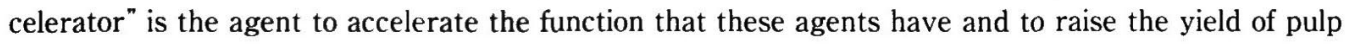
furthermore.

In the bleaching process, chlorine is used as one of the bleaching agents. But it may cause the occurrence of dioxin. so it is better to decrease the amount of chlorine consumption from the environmental point of view. "Oxygen Bleaching Accelerator" can raise the ratio of delignification yield and decrease the amount of not only chlorine but also sodium hydroxide and chlorine dioxide.

Both agents are useful in the Kraft process, and can be expected in the future.

分類： $W_{1}$ 蒸解薬品, $F_{2} \mathrm{KP}$ 蒸解

\section{1.はじめに}

2001 年度の日本における紙の生産量は, 年間約 3,000 万トンにもおよび, 世界有数の生産規模を誇っ ている。近年, 情報化社会の構策が目覚しい勢いで進 んでいることにより，少しずつペーパーレス化へと移 行する動きがあるが, 紙の利便性を完全に覆すまでに はまだ至らず, 紙の生産量は今後しばらくの間この水 準を維持するものと思われる。紙の原料であるパルプ は，主にセルロース纎維とリグニンより成る木材から， セルロース䄉維を分離して取り出すことによって得ら れる。パルフ製造法のうち, 最も広く普及しているの がリタンンを化学薬品で溶かし出してセルロース䄉維

*平成 14 年度年次大会講演（講演 No. D 3）
を取り出すクラフトパルプ (KP) 法であり, 国内製 造パルプの約 $85 \%$ を占めている。KP 法は, (1)蒸解 時間が短く連続・大量生産に適している，(2ほとんど 全ての樹種に適用でき品質の良いパルプが生産できる, (3)廃液からの薬品および熱の回収法が確立しているな どの特長を有し，非常に優れたパルプ製造法である。 反面, 得られるパルプの収率が低いことが欠点であり, パルプの収率をいかに向上するかが大きな課題である。 KP 法で得られたパルブは着色成分（リグニン）を 含有しているが，大半はさらに漂白処理が行われ，漂 白パルプ (BKP) となる。漂白については工業的に は多段漂白法が採用され，中でも O-C-E-H-D 系の 漂白シーケンスを採用している所が大半を占めている。 近年ダイオキシン問題がクローズアップされているこ とから,タイオキシン発生源である塩素の使用量をい 


吉䪺吾

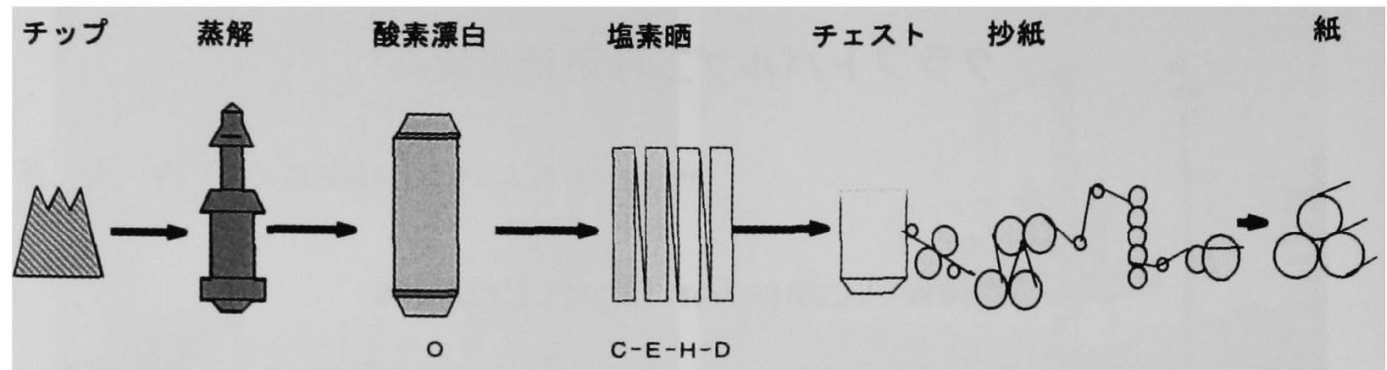

困 1 漂白パルプ（BKP）の製造工程

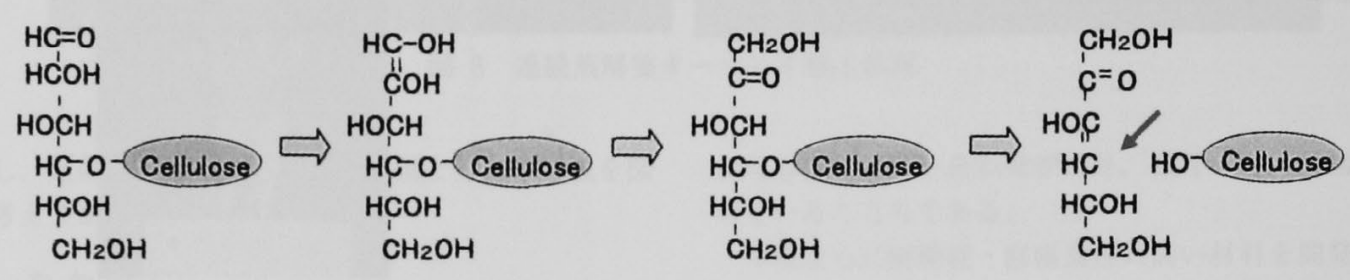

図 2 セルロースの分解反応（ピーリング反応）

かに削減できるかが大きな課題となっている。図1に BKP 製造プロセスの概略を示す。

ここでは，BKPを製造するうえで，多くの効果が 期待できる 2 つ薬片, 蒸解促進郕と酸素漂白促進剤 について紹介する。

\section{2. 蒸解促進剤}

\section{1 蒸解促進剂とは}

蒸解は，木材 (チップ)を $160 \sim 170^{\circ} \mathrm{C}$ の高温にて 白液（アルカリ，硫化ソーダの水溶液）で蒸煮し，パ ルブを得る丁程である，本処理により得られるパルプ の収率は約 50\%であり，機械パルプ (GP) の場合の 約 $90 \%$ に比べると非常に低い。その原因は、アルカ リ存在下でセルロースが分解し，溶出していくためで ある（ピーリンク反忍，図2)。これを防ぐためには， セルロース末端にあるアルデヒド基を酸化して安定化 してやればよい。この目的で使用されるのが蒸解助剤 であり、アントラキノン（AQ）をはじめとしたアン トラキノン誘導体扰よびポリサルファイド系の化合物 が一般に使用されている。図3に $\mathrm{AQ}$ を使用した場

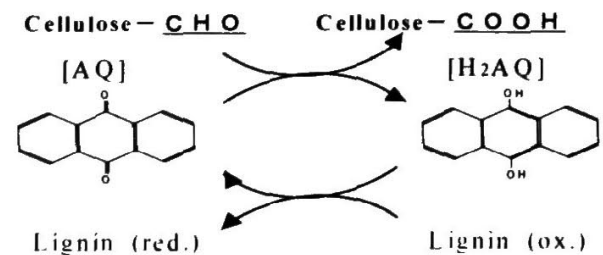

図 $3 \mathrm{AQ}$ の作用機序
合の作用機構を示す。 $\mathrm{AQ}$ はセルロースの末端アルデ ヒド基を酸化して, 自身は還元される。この還元物 $(\mathrm{H}$

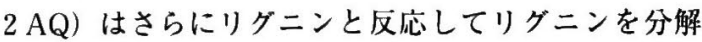
する。自身はもとの $\mathrm{AQ} に$ 戻り，再生される。この ように、 AQ はセルロース分解防止によるパルプ収率 向上効果だけでなく,リクニンの分解促進効果も有し た非常に優れた薬郕である。

この効果を効率よく発現させるためには，チップ中 の七ルロースに蒸解助剤を十分に作用させなければな らない。蒸解促進郕はこの作用を助け，蒸解助郕の優 れた機能を促進する薬剤である。蒸解時間は限られて いるため，七ルロースと蒸解助剂の作用は速やかに起 こる必要がある。従って, 本薬剤に要求される機能は, チップ中への $\mathrm{AQ}$ の浸透性向上である。 $\mathrm{AQ}$ は白液中 に溶解しているため，白液の浸透力を向上させれば本 機能が満たされる。また，もう一つ要求される機能と して, 発泡抑制がある。蒸解後の洗浄工程で泡が大量 に発生すると，洗浄速度の低下による生産性低下，洗 浄不良によるパルプ品質低下などのトラブルが発生す る。このためには，抑泡・脱泡性に優れた成分を選定 する必要がある。浸透力の向上には, 界面活性剤が威 力を発揮し, さらに泡立ち制御の観点から, 非イオン 性の界面活性剤の使用が最も有効である。

\section{2 蒸解促進刘の効果}

蒸解促進淳を併用することにより期待できる効果を 以下に示す。

(1) $\mathrm{KP}$ 収率の向上

セルロースへの蒸解助剤の作用を促進することによ 
りセルロースの分解を素早く防止し, KP 収率を向上 させ，原料コストを低減させることができる。

(2) カッパー価の低減

蒸解助郕にはリグニンの分解効果もある。蒸解促進 片を併用すると, リグニンの分解が促進され，その結

果、KP のカッパー価をより低下させることができる。

(3) 薬品使用量の低減

蒸解促進剤の併用により KPのカッパー価が低下す るが, カッパー価を低下させる必要がない場合は，KP 製造に必要な活性アルカリ量を低減させることができ る。これにより, 薬品コストのダウンが可能である。

その他期待できる効果として、ユーティリティーの 低隇と蒸解塔内のスケール付着防止が考えられる。前 者については, 先の薬品使用量低隇の場合と同じく, カッパー価を低下させる必要がない場合は, 蒸解促進 剤の併用により，KP 製造時の蒸解温度低下, 蒸解時 間の短縮効果が見込まれる。後者については, 界面活 性剤である蒸解促進㣂が蒸解塔内の無機物、 AQ, そ の他有機物等に起因するスケールを乳化・分散・可溶 化することにより，壁面への付着を防止しうると考え ている。

\section{3 評価結果例}

以下に弊社ラボおよび実機における評価結果を示す。

\subsection{1 ラボでの評価結果}

蒸解促進剤「リグノルパーDI-750」を使用した 弊社ラボ評価結果を図4に示す。チッブは広葉樹（L 材）を使用し、「リグハソルパーDI-750」の使用量は チップの絶乾質量に対し固形分で 100 質量 $\mathrm{ppm}, \mathrm{AQ}$ の使用量はチップの絶乾質量に対し固形分で 500 質量

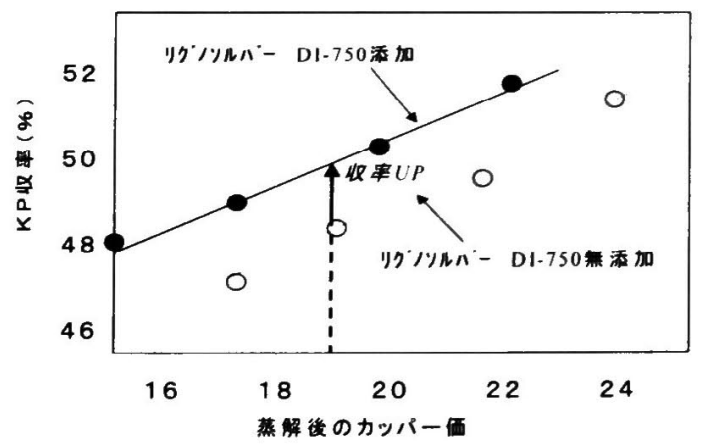

《試験条件>

蒸解温度： $165^{\circ} \mathrm{C}$, 蒸解時間：100 分, 硫化度：30\%, 活性アルカリ添加率：13〜 $16 \%$, 液比：4, リグノソ ルバーDI-750 添加率 : 100 質量 $\mathrm{ppm} /$ 絶乾チップ $\mathrm{AQ}$ 添加率 : 500 質量 $\mathrm{ppm} /$ 絶乾チップ

図 4 蒸解後のカッパー価と KP 収率の関係 ppm とした。なお,「リグノソルバーDI-750」の使 用量は, 通常チップの絶乾質量に対し固形分で 25 200 質量 ppm である。

図 4 より，「リグノソルバーDI-750」による KPの 収率向上効果が認められる。同一カッパー価, 例えば カッパー価 19 のところで比較すると,「リクノソルバ —DI-750」の併用により，KP 収率が「リグノソルバ 一DI-750」無使用時に比べ約 1.8\% アップしている。 一方, 同一の KP 収率で比較した場合は, カッパー価 を低下させることができる：図 4 にみられるように，

「リグハソルバーDI-750」を併用することにより，蒸

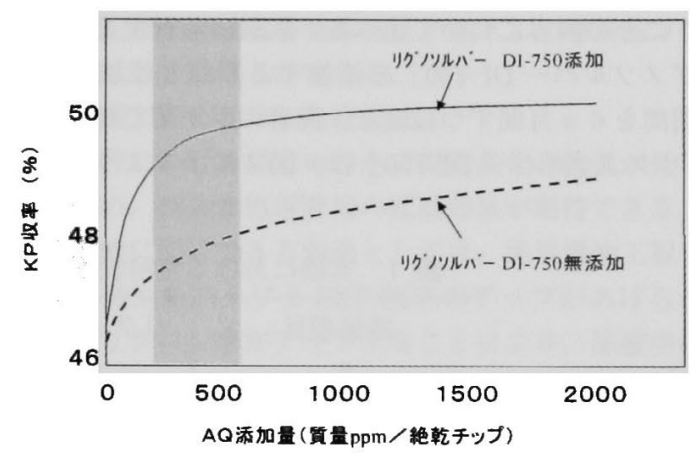

<試験条件>

蒸解温度： $165^{\circ} \mathrm{C}$, 蒸解時間：100 分, 硫化度：30\%, 活性アルカリ添加率：14\%, 液比：4, リグノソルバ - DI-750 添加率：100 質量 ppm/絶乾チップ

図 $5 \mathrm{AQ}$ 添加量と $\mathrm{KP}$ 収率の関係

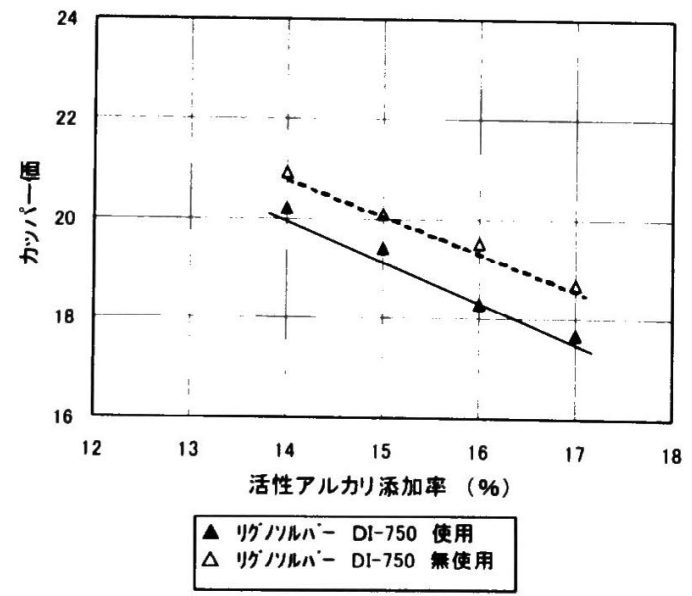

<試験条件>

蒸解温度： $160^{\circ} \mathrm{C}$, 蒸解時間： 120 分, 硫化度： $30 \%$, リクノソルパーDI-750 添加率：100 質量 $\mathrm{ppm} /$ 絶 乾チップ $\mathrm{AQ}$ 添加率： 500 質量 $\mathrm{ppm} /$ 絶乾チップ

図 6 活性アルカリ添加率とカッパー洒の関係 
解後のカッパー価が 2 4 ポイント低下している。

つぎに,「リグハソルバーDI-750」を併用した場合 の $\mathrm{AQ}$ の添加量と $\mathrm{KP}$ 収率の関係を図 5, 同様に活性 アルカリ添加率とカッパー価の関係を図 6 に示す。こ れらの実験も広葉樹（L材）を使用して行った。図 5 より，AQの通常の添加量 200 500 質量 $\mathrm{ppm} /$ 絶乾 チップで「リグノソルバーDI-750」を併用すること により，収率向上効果が認められる。また，図6から 「リグハソルバーDI-750」の添加により, 同一カッパ 一価の場合，活性アルカリ量が低減可能である。

\subsection{2 実機での評価結果}

製紙会社にて 1 年間実機での評価を行ったので，以 下にその内容について述べる。試験は蒸解促進剤「リ グノソルバーDI-750」を添加する期間と添加しない 期間を 6 力月間ずつ設定し，両者の平均値で比較した。 「リグノソルバーDI-750」は，図7に示すように、水
道水と混合して希䣋したものを、コンベアー上を流れ ているチップの上からシャワー状にふりかけて添加し た。チップは広葉樹（L 材）にて行った。

試験結果を表 1 に示す。「リグノソルバーDI-750」 を使用することにより，KP 収率が $1.9 \%$ アップ，カ ッパー価が 0.5 ポイント低下する効果が認められた。 試験時の洗浄機での泡立ちも「リグノソルバーDI750」の有無で特に差は認められなかった。

\section{3. 酸素漂白促進剤}

\section{1 酸素漂白促進剂とは}

白色度の高い紙の需要が多い現在, KP の多くは漂 白処理が施される。2001 年度の実績では, 全 KP 生 産量に占める BKP の割合は約 $85 \%$ にのほる。KPの 漂白处理は，前述したように O-C-E-H-D 系漂白シ ーケンスが現在最も普及している。この多段漂白では,

表 1 実機における蒸解促進剤「リグハソルバーDI-750」の評価結果

\begin{tabular}{l|c|c}
\hline \multicolumn{1}{c|}{ 評価項目 } & $\begin{array}{c}\text { リグハソルバー DI-750 } \\
\text { 使用 }\end{array}$ & $\begin{array}{c}\text { リグハソルバー DI-750 } \\
\text { 無使用 }\end{array}$ \\
\hline $\mathrm{KP}$ 収率 $(\%)$ & 50.4 & 48.5 \\
\hline カッパー価 & 18.5 & 19.0 \\
\hline 洗浄機での泡立ち" & 1.1 & 1.0 \\
\hline
\end{tabular}

<試験条件>

蒸解温度： $155^{\circ} \mathrm{C}$, 蒸解時間： 120 分, 硫化度： $30 \%$, 活性アルカリ添加 率：16 17\%, 液比 : 4, リ グハソルバーDI-750 添加率 : 60 質量 $\mathrm{ppm} /$ 絶 乾チップ, $\mathrm{AQ}$ 添加率: 300 質量 $\mathrm{ppm} /$ 絶乾チップ

蒸解促進郕無使用時の洗浄機での泡高を 1.0 とした場合の相対值で表記

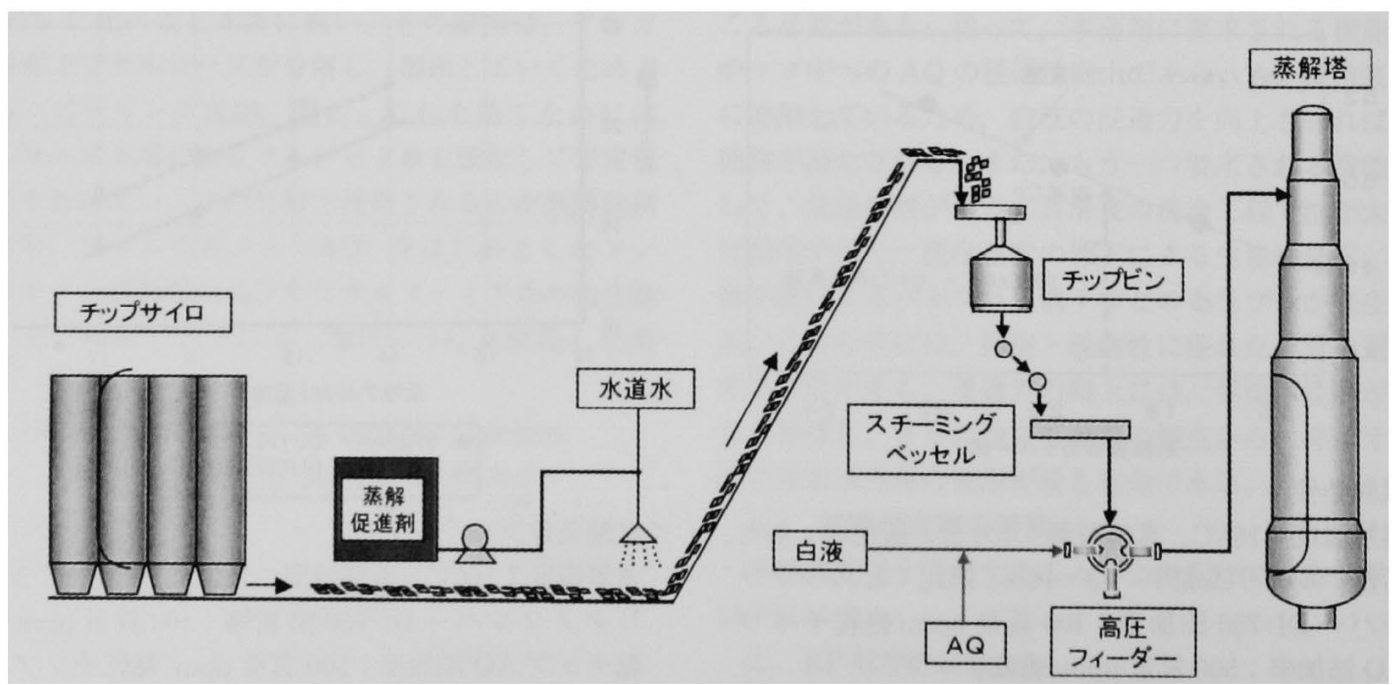

図 7 蒸解促進剤の投入方法 
まずアルカリ条件下で酸素の酸化力を利用して脱りグ ニンが行われ，次に塩素，アルカリを使用して，酸素 漂白で除去することができなかったリグニンが分解し て溶出除去される。そして強い漂白作用を持つ次亜塩 素酸塭および二酸化塩素を使用して漂白が行われる。 最初の脱リグニンが不十分であると，後工程の漂白段 での負担が非常に大きくなるため，O-C-Eの処理段 階での脱リグニンを十分に行っておく必要がある。塩 素の脱リグニン作用は非常に强力であるが，使用によ り発生するダイオキシンの問題があるため, 今後はこ の使用量をいかに低隇するかが大きな課題となる。そ のためには, 前工程の酸素漂白処理により脱リグニン 率をアップさせておくことが最大のポイントになる。

酸素漂白促進郕は，酸素漂白工程における脱りグニ ン率を向上する薬郕である。脱リグニン率を向上させ るためには，アルカリ条件下で KP中に残存するリク ニンと酸素を速やかに反応させる必要がある。従って, 本薬剛に要求される機能の一つは, 前述の蒸解促進剂 と同じく，KPに対する酸素およびアルカリの浸透性 向上，すなわち酸素，アルカリが溶存した楽液の $\mathrm{KP}$ への浸透性向上である。必要な機能の 2 つ目は, 洗浄 工程での泡立ち抑制で，これも蒸解促進刻の場合と同 じである。しかし，酸素漂白の場合は，酸素漂白塔内 において酸素の気泡が適度に発生することが必要であ るため、この段階で泡がすぐに消えてしまうことは脱 リグニン向上させる点からは不都合である。つまり， 本薬剛は, 漂白塔内における酸素気泡の発生と, 洗浄
工程における破泡の 2 つの性能を同時に満たす高度な 泡の制御が必要である。この場合も，非イオン性界面 活性剤の使用が有効である。更にもう一つ必要な機能 は，パルブ織維から剥離したリグニンがパルプ織維に 再付着するのを防ぐことである。このためにはリグニ ンを処理液中に乳化・分散させればよく，高分子型の 界面活性郕が適している。

\section{2 酸素漂白促進剤の効果}

以下，酸素漂白促進剮を使用することにより期待で きる効果について説明する。

1. 酸素漂白工程における脱リグニン率の向上

酸素漂白工程における脱リグニン率の向上により，

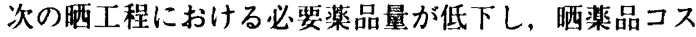
卜を低減させることができる。

2. 唒工程における負荷低減

唒工程における排水中の全有機塩素化合物量が低下 するため, 眖排水処理費用の低減効果が期待できる。

その他に期待できる効果としては，黒液燃焼工程で の蒸気発生量アップと BKP 収率のアッブがあげられ る。脱リグニン率がアップすることにより，黒液中の リグニン濃度が高くなる。その結果，黑液燃焼工程で の固形分が多くなり，燃焼による蒸気の発生量がアッ プすることが期待される。一方，収率アップのほうに ついては、脱リグニン率の向上により，後の晒工程で の必要薬品量が少なくなる。その結果, 晒処理による パルプへのダージが少なくなり，漂白後のパルプの 収率が向上することが期待される。これらはいずれも

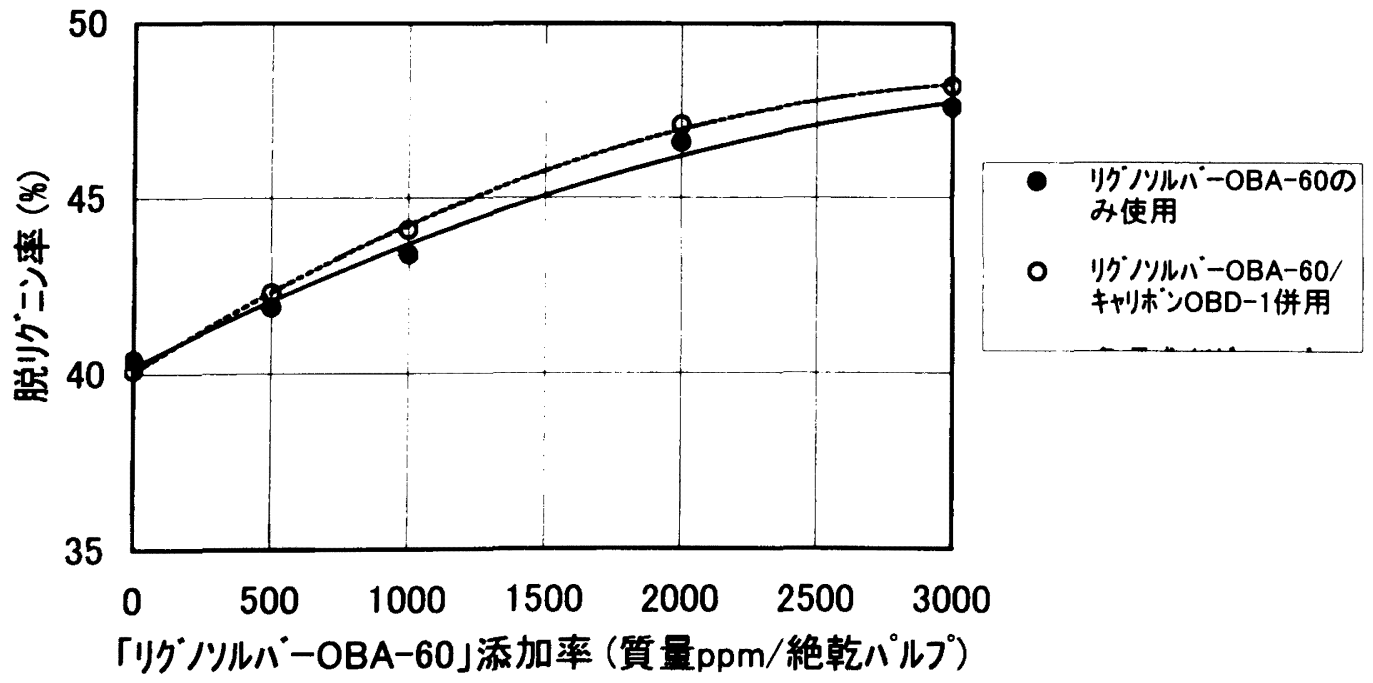

<試験条件>

漂白温度 : $96^{\circ} \mathrm{C}$, 漂白時間 : 40 分, 酸素压：0.64 MPa, キャリボン $\mathrm{OBD}-1$ 添加率 $: 80$ 質量 $\mathrm{ppm} /$ 絶乾パルプ 図 8 酸素漂白促進剤添加量とリグニン率の関係 
コストを低隇させる。

\section{3 評価結果例}

\subsection{1 ラボでの評価結果}

酸素漂白促進剤「リグノソルバーOBA-60」を使用 した弊社ラボ評価結果を図 8 に示す。チップは広葉樹 （L 材）を使用し, 漂白処理時の酸素漂白促進剂濃度 はパルプの絶乾質量に対し固形分で $0 \sim 3,000$ 質量 ppm とした。

図 8 より,「リグノソルバー OBA-60」により, 脱 リグニン率の向上効果が認められる。「リグノソルバ ー OBA-60」の添加量がアップするに従って脱りグニ ン率もアップする。添加量が 3,000 質量 $\mathrm{ppm} /$ 絶乾パ ルプの場合「「リクノソルバー OBA-60」無使用時に 比べ, 脱リグニン率は約 $7.5 \%$ アップした。さらに, リグニンのセルロース瀻維への再付着を防止する作用 のある酸素漂白助剤「キャリポン OBD-1」を併用し た場合は, 併用しない場合に比べ, 脱リグニン率はさ らに約 $0.5 \%$ アップする。

\subsection{2 実機での評価結果}

現在製紙会社にて長期問の実機試験を行っている。 試験開始から約 6 力月が経過した段階での評価状況を 以下に述べる。試験方法は, 酸素漂白促進剤「リグノ ソルパー OBA-60」および酸素漂白助剤「キャリボン OBD-1」を添加する期間と添加しない期間を 1 力月 毎に設け，それぞれの期間の平均値で各性能因子の比 較を行っている。「リグノソルバー OBA-60」および 「キャリボン OBD-1」は, 図 9 に示すように, 酸素

漂白塔の手前にある KP 用洗浄機の出口に投入する。 投入量は, 珮面を考慮し, 定常状態における酸素漂白 塔内での本酸素漂白促進刜の濃度が周形分で約 1,700
質量 $\mathrm{ppm} /$ 絶乾パルプになるように，固形分で 310 質 量 $\mathrm{ppm} /$ 絶乾パルプで行っだ。投入方法はポンプを使 用して原液のまま連続投入する。

表 2 に結果を示す。酸素漂白促進剤により, 脱リグ ニン率は酸素漂白促進剤無使用時に比べ約 5\%アッフ している。これは, 前述の弊社ラボにおける評価結果 とほほ一致する値であり，両者の間に相関があること を示している。次に晒工程での薬品（塩素, 苛性ソー ダ, 二酸化塩素）使用量についてみると, 塩素, 苛性 ソーダは 6〜 7\%，二酸化塩素の場合は $13 \%$ もの量が 酸素漂白促進剤を使用していない場合に比べて低減さ れている。これらのデータより，実機における長期試 験においても本薬剤使用による脱リグニン率向上効果 および晒工程での負荷軽隇効果を確認することができ た。また，洗浄機における発泡性についても，酸素漂 白促進剤添加による泡立ち增加は認められなかった。

\section{4.おわりに}

以上, KP 法において今後大きく期待できる $2 つ の$ 薬剂について紹介を行った。蒸解促進剤は，KP 法に おける最大の欠点を改善することができる有効な薬剂 である。パルブ収率を上げることができるため，パル プ製造に必要なチップの量が少なくて済む。その結果, 貴重な森林資源を守ることにつながるため，環境問題 解決の観点からも好ましい薬㓮である。一方, 酸素漂 白促進剤は，その使用により生物にとって有害なダイ オキシン発生量の低減に結びつくことから，より環境 問題への貢献度が大きな薬剤である。漂白工程につい ては, 今後 ECF（Elementary Chlorine Free）化が進 行するものと予想される。2段酸素漂白や高濃度酸素

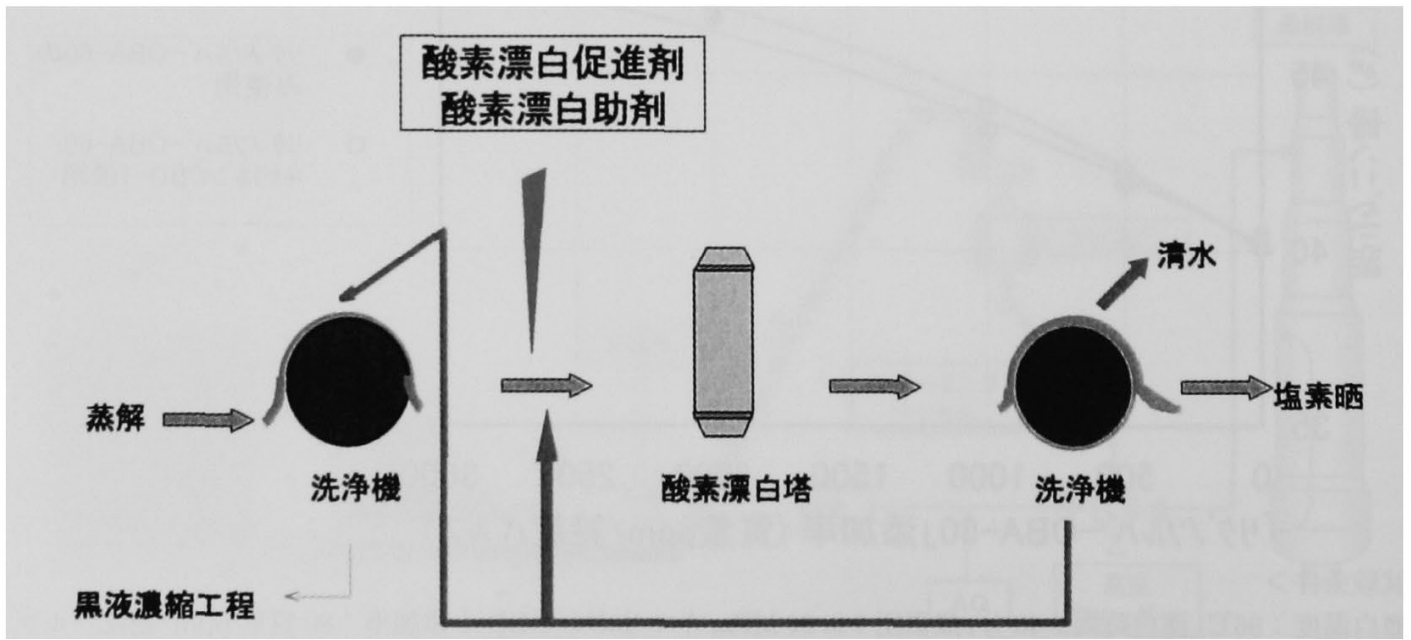

図 9 酸素漂白促進剂および酸素漂白助剤の投入方法 
表 2 実機における酸素漂白促進剤の評価結果

\begin{tabular}{|c|c|c|c|}
\hline \multicolumn{2}{|c|}{ 評価項目 } & 促進剤および助剤使用 & 促進剂および助剤無使用 \\
\hline \multicolumn{2}{|c|}{ 脱リグニン率（\%） } & 44.9 & 40.1 \\
\hline \multirow{3}{*}{$\begin{array}{l}\text { 晒薬品 } \\
\text { 低減率 }\end{array}$} & 塩素 (\%) & 6.2 & - \\
\hline & 苛性ソータ（\%） & 6.8 & - \\
\hline & 二酸化塩素（\%） & 13.2 & - \\
\hline \multicolumn{2}{|c|}{ 消泡剂使用量 } & 0.95 & 1 \\
\hline
\end{tabular}

<試験条件>

リグハソルバー OBA-60 添加率 : 310 質量 $\mathrm{ppm} /$ 絶乾パルプ3, キャリボン OBD1 添加率: 15 質量 $\mathrm{ppm} /$ 絶乾パルプ, 漂白温度: $93 \sim 96^{\circ} \mathrm{C}$, 漂白時間 : 40 分, 酸 素压: $0.64 \mathrm{MPa}$

"漂白促進郕および漂白助剤無使用時の值に対する低隇率で表記

${ }^{21}$ 漂白促進剮および漂白助剤無使用時のレベルを 1 としたときの相対値

31 酸素漂白塔内における濃度が, 1,700 質量 $\mathrm{ppm}$ /絶乾パルプとなるように添加し た場合の添加量

漂白等の高度な漂白設備を導入し酸素漂白をさらに進 める動きもあるが，その場合においても本楽剤の効果 が発揮されるものと期待される。これら 2 つの薬郕に ついて, 現在の難題は実際の効果が定量的に把握しに くいことである。これは対象となるチッブが天然物で あるために原料組成の変動が大きく，それが測定デー 夕や性能に影響を及ほすためである。また KP 製造に
おける変動因子が多いことも理由に挙げられる。現在, 我々はこれらの問題を解決すべく, 変動因子の変化を 考慮に入れた効果の確認方法の確立に力を入れている。 そして, 将来的には更なる性能向上をはかっていきた いと考えている。

\section{参考文献}

1）紙・パルプ統計月報（平成 13 年 12 月分） 


\section{報 文 既 要 一 筧}

\section{連続蒸解金オーバーレイエ法の開発について}

ダイオーメンテナンス株式会社 開発部 伊藤 雅童

今まで国内では炭素銅で製作された連続蒸解釜は桼品及びチッブによる腐食・摩耗により減肉が発生 するため，延命化対策としてステンレスブレートによるライニングを実施してきた。しかしステンレス プレートによるライニングは溶接部の腐食および焦応力による笠が発生する可能性が高く，従来より 改善が望まれていた。今回大王製紙株式会社の NKP 連続蒸解釜の延命化対策として肉盛溶接（オーバ ーレイ）を当社と日铁ハード㮫で協同開発し, 2002 年 3 月に洗浄ソーン $110 \mathrm{~m}^{2}$ を施工した。当社のオー バーレイエ法の特㣲は以下の 2 点である。

(1) 施工工期を最大限に短縮

自助昇降式ステージを使用することで，オーバーレイ装置の組立・解体，溶接面の検査が短時間で 施工可能となった。

(2) 高い作菜安全性を確保

従来の銅管材，丸太による足場に比べ，転落の危険性がなく動力で昇降できる自動昇降式ステーシ により安全に連続蒸解釜内全面の洗浄・修理・点検が可能となった。

今後, 従来の SUS 304 L クラッド釾の摩耗にも対応できる溶接材料も開発し，安全に，短い工期で国 内の製林会社に連続蒸解釜の延命化対策を提供していく。

(本文 51 ページ)

\section{クラフトパルプ工程用新規薬剤}

サンノブコ株式会社 研究棯括部 吉内 圭吾

クラフト法は非常に優れたバルプ製造方法であるが，最大の久点は，蒸解によるパルプの収率が低 いことである。この久点を改善すべく，アントラキノン誘幕体やボリサルファイド系の化合物がパルフ の収率向上菜郕 (蒸解助剂) として幅広く使用されている。“蒸解促進剤”は, これら蒸解助剂の優れ た機能を促進する来郕であり，使用することによりパルプの収車をさらに上げることができる。また， 蒸解助郕はリグニンの分解作用も有するため，本蒸解促進剤の使用によりパルプのカッパー価をさらに 低下させることもできる。

蒸解後の漂白方法には多段漂白法が採用されており，中でも酸素漂白工程と晒工程を採用している所 が大半を占めている。唒工程では，堭素が主な漂白薬品として使用されているが，この使用はタイオキ シン発生の原因となりうろため, 環境問題の钼点からみると, 今後は塩素の使用量を娍少させていくこ とか好ましい。“酸素漂白促進郕”は，酸素漂白工程における漂白性を向上，すなわち脱りダニン事を 向上させる莱剂である。これにより，塩素のみならず，苛性ソータ，二酸化㙁素など，唒工程で使用さ れている漂白省品の消量を娍少させることができる。さらに，この奻果発現に伴い，晒工程から排出 される排水中の全有機物塩素化合物旦の低下による排水処理费用低娍奻果も期待される。

これらはいずれもクラフト法において有用であり，将来が期待される萂詴である。

(本文 55 ベージ) 